\title{
PERMAINAN SAINS PROBLEM-SOLVING CARDBOARD BOX LEGO DAN KREATIVITAS ANAK USIA DINI
}

\author{
Science Solving Cardboard Boxlegod Games and Early Children's \\ Creativity
}

\author{
Sarah Fauziah ${ }^{1}$ Edi Hendri Mulyana ${ }^{2}$ Sima Mulyadi ${ }^{3}$ \\ Universitas Pendidikan Indonesia Kampus Tasikmalaya ${ }^{123}$ \\ Email: sarahfauziah565@upi.edu1 1 \\ Email: edihm@upi.edu² \\ Email: sima_mulyadi@upi.edu 3
}

\begin{abstract}
DOI: $10.53754 /$ edusia.v1i1.48
Received: 12 August $2021 \quad$ Revised: 18 August 2021

Approved: 23 August 2021

Abstract: Media, in general, is a means of providing information to the recipient of the message, namely the child. The game is a medium that is used as a medium of play for children that can be used as a means of learning. This game uses a problem-solving learning method, namely problem-solving. It is hoped that this method can find solutions in fostering children's creativity. Therefore, this research is to improve children's cognitive abilities in solving a problem (problem-solving). Thus, this research develops problem-solving game media to facilitate children's creativity by using cardboard box lego game media. In designing this game media, it refers to the 2013 curriculum. The 2013 curriculum is expected to facilitate aspects of children's cognitive development for their creativity. This study aims to describe the basic needs of game media and develop a cardboard box lego problemsolving science game to facilitate early childhood creativity. The method used in this research is the Educational Design Research (EDR) floating method. Learning science in early childhood is still considered quite tricky, but this will be easy to overcome with the right and appropriate and adequate media and teaching materials. Based on the literature study that has been done, many science game media are not by the child's development stage, which should adjust to aspects of child development that refer to the 2013 curriculum. So based on the needs and findings in the field, researchers will develop a cardboard box kego problem-solving science game to facilitate early childhood creativity.
\end{abstract}

Keywords: Science Games, Problem Solving, Cardboard Box Lego, Creativity

Abstrak: Partisipasi orang tua sangat mendasar dalam kemajuan karakter anak, salah satunya kecerdasan. Kecerdasan intrapersonal sangat penting bagi anak, jika seseorang memiliki kecerdasan ini dengan tingkat tinggi maka akan mampu mengontrol emosinya sehingga tindakan yang dilakukan didasarkan pada pengetahuan yang benar. Oleh karena itu, dalam mengembangkan kecerdasan intrapersonal ini diperlukan stimulus dari orang tua. Maksud dibalik penelitian ini adalah untuk menggambarkan peran orang tua dalam mengembangkan kecerdasan intrapersonal anak-anak usia 5-6 tahun. Peneliti menggunakan metode kualitatif dengan pendekatan studi kasus, jenis pendekatan studi kasus instrumental. Pemilihan subjek penelitian dilakukan dengan cara purposive sampling yaitu terdiri dari dua keluarga. Metode pengumpulan informasi ini, dilakukan dengan menggunakan wawancara, observasi, dan dokumentasi. Penelitian ini menggunakan teknik analisis data yang diciptakan oleh Miles dan Huberman. Hasil penelitian menunjukkan bahwa orang tua berperan dalam memberikan dukungan, orang tua berperan dalam memberikan bimbingan, orang tua berperan dalam memantau kegiatan anak, orang tua 
Permainan Sains Problem-Solving Cardboard Box Lego dan Kreativitas Anak Usia Dini

berperan memberikan pemahaman bagi anak, orang tua mengajarkan anak dalam meredam emosi, orang tua berperan melakukan pembiasaan pada anak.

Kata Kunci: Pariwisata, wisata edukasi, pengembangan desa, pemberdayaan masyarakat 


\section{PENDAHULUAN}

Pendidikan pada anak usia dini pada dasarnya Masa ini biasa disebut masa cemerlang. Oleh karena itu, orang tua, pendidik, dan masyarakat sekitar perlu memberikan contoh yang sesuai untuk membina semua sudut yang ada pada anak, salah satunya dengan memberikan bimbingan,arahan dan pendidikan. Undangundang Nomor 20 Tahun 2003 Pasal 1 no 4 yang menyatakan bahwa pendidikan anak usia dini merupakan pembinaan yang ditunjukan untuk anak usia 0-6 tahun untuk memberikan dorongan, membantu perkembangan dan peningkatan baik secara jasmani dan rohani untuk memiliki persiapan pendidikan berikutnya.

Salah satu upaya dan tindakan yang dilakukan oleh pendidik dan orang tua dalam proses perawatan, pengasuhan dan pendidikan pada anak dengan menciptakan aura dan lingkungan dimana anak dapat mengeksplorasi pengalaman yang memberikan kesempatan kepadanya untuk mengatahui dan memahami pengalaman belajar yang diperolehnya dari lingkungan, melalui dengan cara mengamati, meniru dan berekasperimen yang berlangsung secara berulang-ulang dan melibatkan seluruh potensi dan kecerdasan anak.

Dalam proses mencari potensi anak maka problem solving cardboard box lego sebagai upaya meningkatakan pengembangan kecerdasan anak yaitu dengan aspek perkembangan kognitif untuk memfasilitasi kreativitas anak. Dalam penelitian ini ada 5 referensi diantaranya: (1) ${ }^{1}$ bahwa imajinasi itu penting untuk diciptakan mengingat daya cipta mempengaruhi kehidupan seseorang, misalnya inovasi mempengaruhi pemikiran seseorang, mengatasi suatu masalah, dan mempengaruhi presentasi belajar; (2) ${ }^{2}$ mengatakan bahwa pemanfaatan bahan bekas menjadi media pembelajaran dapat meningkatkan kreativitas siswa. Berdasarkan penelitian tersebut, penelitian tindakan dan analisis penelitian terkait dengan peningkatan kreativitas anak melalui media bahan bekas yaitu kardus tenyata berhasil dalam penelitian ini; (3) ${ }^{3}$ menyatakan bahwa Anak-anak yang dapat mengatasi masalah mereka sendiri menunjukkan bahwa kapasitas intelektual dalam penalaran dan imajinasi dapat berkembang dengan baik. Oleh karena itu, latih anak untuk memiliki pilihan dapat menangani masalah mereka sendiri tanpa bantuan orang lain. Ini harus dilakukan dengan cara yang keren dan menarik, khususnya bermain dengan media permainan yang tepat seperti lego, puzzle, maze,

\footnotetext{
${ }^{1}$ Diana Vidya Fakhriyani, "Pengembangan Kreativitas Anak Usia Dini," Wacana Didaktika 4, no. 2 (2016): 193-200, https://doi.org/10.31102/wacanadidaktika.4.2.193-200.

${ }^{2}$ Anistya Rachmandani, "Peningkatan Kreativitas Anak Melalui Media Bahan Bekas Pada Siswa RA Kelompok B Di RA Miftahul Huda 1 Lopait Kecamatan Tuntang Kabupaten Semarang Tahun Pelajaran 2016/2017," Skripsi, 2017, 1.

${ }^{3}$ Ii Wartini et al., "Penerapan Metode Problem Solving," Tunas Siliwangi 3, no. 2 (2017): 175-80.
} 
labirin atau bermain peran; (4) ${ }^{4}$ mengemukakan bahwa kreativitas itu kemampuan anak-anak membantu dalam mengintegrasikan fitur-fitur yang menentukan kreativitas (kebaruan dan utilitas) akan meningkat seiring bertambahnya usia; (5) 5 dari hasil penelitian menunjukan bermain lego secara harian dapat mengembangkan kemampuan kreativitas anak dalam implementasi ide-ide abstrak menjadi konkrit bersamaan pengembangan pemahaman bidang yang lain, terutama dalam sains dan matematika, secara sinergi dimana guru telah memberikan jaminan suasana yang bebas dan kondusif bagi terciptanya ide-ide kreatif selama bermain. Dari kelima pendapat tersebut maka peneliti mengabungkan penelitian ini, yang telah dilaksanakan oleh peneliti sebelumya melalui media permainan untuk anak dengan didukung oleh berjudul "Pengembangan Permainan Sains Problem Solving Cardbaord Box Lego untuk Memfasilitasi Kreativitas Anak Usia Dini".

Kreativitas berdasarkan uji coba yang telah dilakukan bahwa kreativitas anak, kita harus benar-benar memahami lingkungan yang mengitarinya kondusif untuk mengarah kepada permainan yang dapat meningkatkan aspek perkembangan yang mengantarkan kognitif anak untuk memfasilitasi kreativitas anak. Dengan cara metode permainan mengunakan model pembelajaran problem solving (pemecahan masalah). Sebab problem solving merupakan mempersiapkan anak agar anak berpikir dalam mengatasi masalah secara tepat, mendasar, dan efisien sehingga dengan strategi ini anak akan dapat berpikir lebih tenang sehingga tidak terburuburu dibutuhkan waktu yang cukup dalam menyimpulkan suatu masalah sebab pada dasarnya dunia anak adalah dunia bermain, sehingga membutukan waktu cukup untuk pemecahan yang mehasilkan suatu produk yang sesuai dengan harapan. Sains dalam permianan disini dituntut melakukan percobaan-percobaan bongkar pasang dengan permainan yang menyenangkan untuk mengarah kepada pembelajaran melalui hasil pengamatan, eksperimen dalam berpikir sehingga menghasilkan suatu produk yang mempunyai fungsi serta bentuk yang diharapkan. Maka dalam penelitian ini saya mengunakan "Pengembangan Permainan Sains Problem Solving Cardbaor Box Lego untuk Memfasiltasi Kreativitas Anak Usia Dini" dengan langkah mengunakan metode EDR yaitu ada 3 tahap: (1) Identifikasi dan analisis masalah oleh peneliti dan praktisi secara kolaboratif.; (2) Mengembangkan prototype solusi yang didasarkan pada patokan teori, design principle yang ada dan inovasi teknologi.; (3) Melakukan proses berulang untuk

\footnotetext{
${ }^{4}$ Laura W. Stricker and David M. Sobel, "Children's Developing Reflections on and Understanding of Creativity," Cognitive Development 55 (2020), https://doi.org/10.1016/j.cogdev.2020.100916.

5 Adella Fadilatunnisa, Nur Khasanah, and Supriyati H Rahayu, "Bermain Lego Sebagai Pembelajaran Harian Untuk Mengembangkan Kreatifitas Anak Usia Dini" 3 (2021), https://doi.org/10.35473/ijec.v3i2.1005.
} 
menguji dan memperbaiki solusi secara praktis.; (4) Refleksi untuk menghasilkan design principle serta meningkatkan implementasi dari solusi secara praktis.

Peneliti bermaksud merancang produk untuk mengembangkan permainan sains untuk memfasilitasi kreativitas anak. permasalahan yang akan di angkat dalam penelitian ini adalah kurangnya anak berpikir kreatif pada masa sekarang dan banyaknya anak yang di tuntut untuk belajar saja serta dituntut perpikir praktis. Diharapkan dengan suatu permainan sains yang akan diangkat, menumbuhkan daya cipta anak serta memanfaatkan perantara media Cardbaord Box Lego yang mudah dicari, ekonomis dan membantu pihak sekolah dalam pengadaan Alat Permainan Edukasi (APE).

\section{PEMBAHASAN}

\section{Problem Solving}

Problem Solving merupakan suatu proses yang dirancang untuk membantu siswa dalam memecahkan masalah. Problem solving bermakna ganda yaitu proses memecahkan masalah itu sendiri dan hasil dari upaya memecahkan masalah atau solution (solusi) ${ }^{6}$. Pernyataan ini diperkuat oleh Djamarah \& Zain (2010) ${ }^{7}$ menyatakan bahwa model pembelajaran problem solving adalah model pembelajaran yang memderi peluang mahasiswa untuk memecahkan masalah yang secara mandiri sehingga mampu memperoleh konsep dan kemudian mampu menerapkan konsep yang telah diperolehnya untuk memecahkan masalah dalam bentuk lainnya.

1. Kemampuan Pemecahan Masalah

Untuk memperoleh kemampuan dalam pemecahan masalah, seseorang harus mempunyai banyak pengalaman dalam memecahkan berbagai masalah. Berbagai hasil penelitian menunjukkan bahwa anak yang diberi banyak latihan pemecahan masalah memiliki nilai lebih tinggi dari pada anak yang latihannya lebih sedikit ${ }^{8}$. Penyelesaian memerlukan suatu kreativitas, pengertian dan pemikiran/imajinasi dari setiap orang yang menghadapi masalah tersebut.

Menurut G. Polya ${ }^{9}$ ada empat langkah di dalam memecahkan suatu masalah yaitu pertama mengerti terhadap masalah, kedua buatlah rencana untuk menyelesaikan masalah, ketiga cobalah atau jalankan rencana tersebut, dan yang keempat lihatlah kembali hasil yang telah diperoleh secara keseluruhan.

\footnotetext{
${ }^{6}$ (Asfar \& Nur, 2018, p. 11)

7 (dalam Asfar \& Nur, 2018)

8 Wartini et al., "Penerapan Metode Problem Solving."

9 (dalam Asfar \& Nur, 2018)
} 
10 Pemecahan masalah merupakan kemampuan dasar yang harus dikuasai oleh siswa. Bahkan tercermin dalam konsep kurikulum berbasis kompetensi. Menumbuhkan kemampuan siswa dalam berpikir kritis adalah dengan memberikan pertemuan berpikir kritis yang membutuhkan berbagai teknik mulai dari satu masalah kemudian ke masalah berikutnya. Pembelajaran berpikir kritis tidak setara dengan masalah pembelajaran yang telah diselesaikan (berpikir kritis).

Kapasitas anak-anak untuk menangani masalah secara tegas diidentifikasi dengan tingkat peningkatan mereka. Dengan cara ini, masalah yang diberikan kepada anak-anak dengan tingkat kesulitan harus disesuaikan dengan giliran mereka.

2. Pengembangan Model Pembelajaran Problem Solving

Menurut ${ }^{11}$ bahwa pengembangan model pembelajaran problem solving dibagi menjadi 6 yaitu sebagai berikut;

a. Merumuskan masalah: mengetahui dan merumuskan masalah secara jelas.

b. Menelaah masalah: menggunakan pengetahuan untuk memperinci menganalisa masalah dari berbagai sudut.

c. Merumuskan hipotesis: berimajinasi dan menghayal ruang lingkup sebabakibat dan alternatif penyelesaian.

d. Mengumpulkan dan mengelompokkan data: kecakapan mencari, menyusun data, dan menyajikan data dalam bentuk diagram gambar, dan tabel.

e. Pembuktian hipotesis: kecakapan menelaah dan membahas data yang terkumpul.

f. Menentukan pilihan penyelesaian: kecakapan membuat alternative pemecahan dan keterampilan mengambil keputusan.

Tabel 1

Langkah Pembelajaran Problem Solving

\begin{tabular}{|c|l|l|}
\hline No & \multicolumn{1}{|c|}{ Fase } & \multicolumn{1}{c|}{ Kegiatan } \\
\hline 1. & $\begin{array}{l}\text { Menyampaikan tujuan dan } \\
\text { mempersiapkan anak. }\end{array}$ & $\begin{array}{l}\text { - Mendengarkan, memperhatikan dan } \\
\text { mengajukan pertanyaan dari cara } \\
\text { penyampaian materi dari pendidik. } \\
\text { Anak mencatat dan mempersiapkan } \\
\text { kebutuhan yang penting. }\end{array}$ \\
\hline 2. & $\begin{array}{l}\text { Atur anak untuk masalah } \\
\text { melalui mengatasi atau }\end{array}$ & $\begin{array}{l}\text { Anak menyebabkan pertanyaan dari } \\
\text { pemikiran atau ide yang mereka }\end{array}$ \\
\hline
\end{tabular}

10 ( Asfar \& Nur, 2018)

11 (Asfar \& Nur, 2018) 


\begin{tabular}{|c|c|c|}
\hline & $\begin{array}{l}\text { perumusan masalah dan } \\
\text { menyatukannya untuk } \\
\text { belajar. }\end{array}$ & $\begin{array}{l}\text { miliki atau ambil dari masalah yang } \\
\text { ada dan digantikan angka atau } \\
\text { gambar dari pertanyaan ini yang } \\
\text { terkait dengan masalah sehari-hari. } \\
\text { - Anak berdiskusi masalah yang akan } \\
\text { diselesaikan } \\
\text { - Anak menelaah permasalahan yang } \\
\text { akan dikaji. }\end{array}$ \\
\hline 3. & $\begin{array}{l}\text { Membimbing penyelesaian } \\
\text { secara individual maupun } \\
\text { kelompok. }\end{array}$ & $\begin{array}{l}\text { - Mengadakan penelitian sehingga } \\
\text { timbul pertannyaan yang harus } \\
\text { dijawab atas masalah yang muncul. } \\
\text { - Anak memakai permasalahannya } \\
\text { dari berita yang didengarnya } \\
\text { sehingga bisa memecahkan hal yang } \\
\text { muncul dan akhirnya keterampilan } \\
\text { pengetahuannya bisa dibiasakan. }\end{array}$ \\
\hline 4. & $\begin{array}{l}\text { Menampilkan akhir dari } \\
\text { penyelesaian masalah }\end{array}$ & 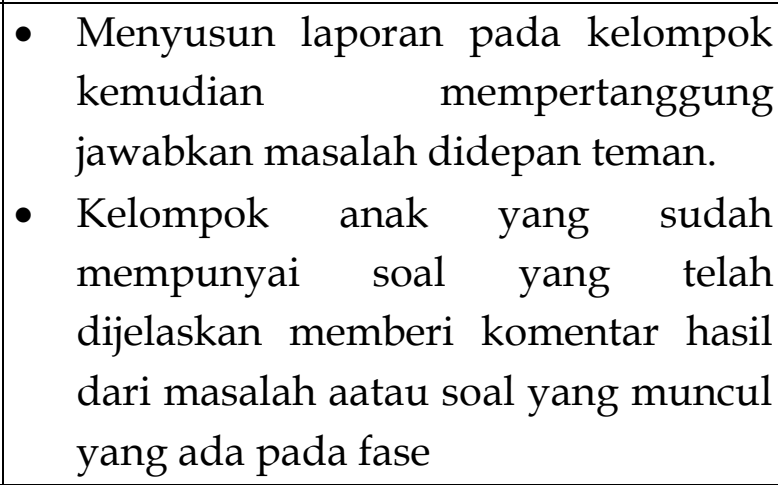 \\
\hline 5. & $\begin{array}{l}\text { Mengoreksi kepahaman } \\
\text { dan Feedback sebagai } \\
\text { penilaian }\end{array}$ & 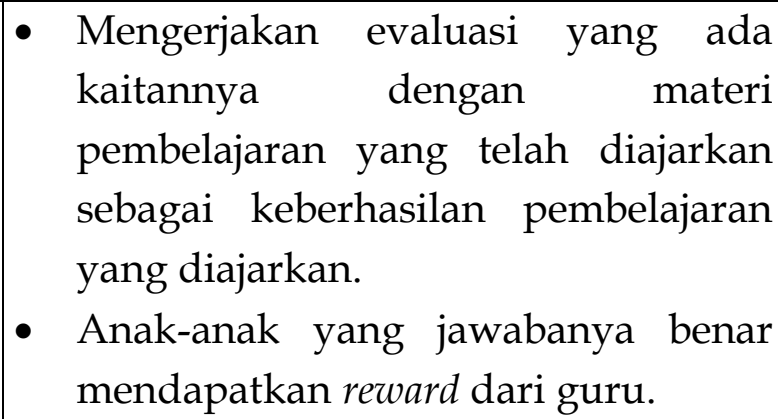 \\
\hline
\end{tabular}

Dari tabel diatas merupakan pendapat 12 bahwa problem solving ada lima langkah/fase dalam proses pemecahan masalah. Maka dari itu penelitian ini akan mengunakan lima fase dalam penelitian yang akan dilakukan dilapangan.

12 (Asfar \& Nur, 2018) 


\section{Kreativitas}

Kreativitas merupakan suatu proses mental individu yang melahirkan gagasan, proses metode ataupun produk baru yang efektif yang bersifat imajinatif, estetis, fleksibel, integrasi, suksesi, diskontinuitas, dan diferensiasi yang berdaya guna dalam berbagai bidang untuk pemecahan suatu masalah ${ }^{13}$.

Ciri Kreativitas adalah salah satu aspek penting dalam kreativitas adalah memahami ciri-cirinya. Upaya menciptakan iklim yang kondusif bagi perkembangan kreativitas hanya mungkin dilakukan jika kita memahami terlebih dahulu sifat-sifat kemampuan kreatif dan iklim lingkungan yang mengitarinya.

Supriadi, $1994{ }^{14}$ mengatakan bahwa ciri-ciri kreativitas dapat dikelompokkan dalam dua kategori, kognitif, dan non kognitif. Ciri kognitif diantaranya orisinalitas, fleksibelitas, kelancaran, dan elaborasi. Sedangkan ciri nonkognitif di antaranya motivasi sikap dan kepribadian kreatif.

1. Kreatif dan Kecerdasan

${ }^{15}$ Kecerdasan dan kreativitas memiliki kaitan yang erat walaupun tidak mutlak. Orang yang kreatif dapat dipastikan ia orang yang cerdas, namun tidak selalu orang orang cerdas pasti kreatif. Lahirnya sebuah karya kreatif, membutuhkan lebih dari sekedar kecerdasan.

2. Kreativitas sebagai Basic Skill bagi Anak Usia Dini

${ }^{16}$ Anak usia 3-4 tahun pun dapat menciptakan apapun yang dia inginkan melalui benda-benda disekitarnya. Hal ini menunjukkan bahwa pada dasarnya anak telah memiliki jiwa kreatif.

Persoalan yang terjadi pada perkembangan selanjutnya daya kreatif anak semakin berkurang. Peraturan-peraturan yang tidak perlu, pola kebiasaan, pola penghargaan, dan pola asuh orang dewasa di sekitar anak dapat menghambat daya kreativitas tersebut.

3. Pengembangan Kreativitas Melalui Imajinasi

17 Imajinasi adalah daya piker untuk membayangkan (di angan-angan) atau menciptakan gambar-gambar (lukisan, karangan, dan sebagainya) kejadian, berdasarkan kenyataan atau pengalaman seseorang. Dalam sumber yang sama imajinasi dapat pula diartikan sebagai khayalan.

Dengan imajinasi anak dapat mengembangkan daya piker dan daya ciptanya tanpa dibatasi kenyataan dan realitas sehari-hari. Imajinasi akan membantu kemampuan berfikir fluency, fleksibelitas, dan originality pada anak.

\footnotetext{
13 (Rachmawati \& Kurniati, 2019, p. 14)

14 (dalam Rachmawati \& Kurniati, 2019)

15 (Rachmawati \& Kurniati, 2019)

16 F Handayani, "Peningkatan Kreativitas Seni Rupa Anak Melalui Media Tekstur Di TK Permata Intan," 2019, https://repository.ar-raniry.ac.id/id/eprint/15219/.

17 (Rachmawati \& Kurniati, 2019)
} 
4. Pengembangan Kreativitas Melalui Aktivitas Menciptakan Produk (Hasta Karya)

18 Pengembangan kreativitas pada anak melalui kegiatan hasta karya memiliki peran penting dalam aspek perkrmbangan kreativitas dan kemampuan kognitif anak. Dalam kegiatan hasta karya anak akan menggunakan imajinasinya untuk membentuk suatu benda sesuai dengan khayalannya. Apapun yang dibuat oleh anak akan membantu mereka menjadi lebih kreatif dan semangat untuk menemukan sesuatu yang baru.

\section{Permainan sains}

Pengembangan dan pengenalan konsep sains pada anak usia dini bersifat mendasar dan mengenalkan suatu kegiatan belajar yang dikemas menyenangkan, menyelidik, dan melakukan suatu percobaan untuk mencari tahu kenyataan dilingkungan alam. Kinzie, dkk $2014^{19}$. pembelajaran sains anak usia dini adalah sebuah pembelajaran yang dikemas untuk mengembangkan pondasi keterampilan sains pada anak yakni dalam pemecahan masalah dan mendorong anak untuk dapat menumbuhkan daya imajinasi ketika melakukan sebuah pengamatan.

Piaget 20, berpendapat bahwa bermain merupakan wahana yang dapat menumbuhkan anak dalam bernalar. Bermain juga merupakan metode belajar yang sangat layak diterapkan pada anak-anak karena pada dasarnya anak-anak belajar sambil bermain, belajar sambil bermain. Sejalan dengan itu Froebel dalam Audrey Curtis dan Bobik ${ }^{21}$ menyatakan bahwa dengan bermain maka kreativitas anak akan berkembang, selain itu anak akan bereksplorasi dengan berbagai objek karena hal tersebut maka pengetahuan serta pemahaman anak akan semakin berkembang tentang segala hal.

Menurut 22 Permainan bongkar pasang tidak jauh beda dengan puzzle ataupun lego dimana permainan bongkar pasar yaitu membongkar dan memasang suatu benda sehingga menjadi bentuk yang diharapkan. Menurut Ismail ${ }^{23}$ masalah atau berpikir kritis pemuda memanfaatkan kapasitas untuk menghadapi dalam memikirkan spekulasi, mengumpulkan informasi dan membuat keputusan atau pilihan. Anak-anak yang bisa mengurus masalah sendiri menunjukkan bahwa psikologis dan perspektif mereka telah maju sehingga anak-anak akan berkembang dengan baik.

Unsur pendidikan dan pembelajaran sains berisi penguasaan proses sains, penguasaan produk sains, serta pengembangan sikap sains.

\footnotetext{
18 (Rachmawati \& Kurniati, 2019)

19 (dalam Paramita et al., 2019)

20 (dalam Bujuri, 2018)

21 (dalam Nadila, 2021)

22 (Nadila, 2021).

${ }^{23}$ (dalam Nadila, 2021)
} 
1. Sains Proses merupakan cara untuk memperoleh pengetahuan, diarakan untuk penguasaan keterampilan yang diperlukan untuk mengali serta lebih mengenal sains. Kebenaran sain akan diakui jika penelusurannya berdasarkan pada kegiatan pengamatan, hipotesis (dugaan), percobaan-percobaan yang ketat dan obyektif, meskipun kadang bersebrangan dengan nilai yang ada. Jika, sains menuntut proses yang dinamis dalam berfikir, pengamatan, eksperimen, menemukan konsep maupun merumuskan berbagai teori. Rangkaian proses yang dilakukan dalam kegiatan sains tersebut, saat ini dikenal dengan sebutan metode keilmuan atau metode ilmiah.

2. Sains sebagai Produk menurut 24 merupakan makna alam dan berbagai fenomena/perilaku/karakteristik yang dikemas menjadi sekumpulan teori dan konsep, hukum, dan prinsip. Sains sebagai produk juga menjabarkan karakteristik-karakteristik ilmu pengetahuan dan sifat-sifat dasar dalam peroses ilmu pengetahuan.

3. Sains sebagai Sikap Ilmiah menurut 25 adalah penanaman sikap-sikap dalam diri siswa (ilmuan) ketika melaksanakan proses metode ilmiah (penyelidikan) dan proses pembelajaran.

Pemberian pembelajaran sains sejak anak usia dini dapat melatih anak dalam menggunakan pemikirannya, kekuatannya, kejujurannya serta teknik-teknik yang dimilikinya dengan penuh kepercayaan diri, sehingga pendidik bertugas mengembangkan program pembelajaran sains yang dapat mengeksplorasi dan beriorentasi sains secara optimal. Maka dari itu, pendidik dapat mencoba membuat sains menjadi lebih menyenangkan dengan membuat media permainan sebagai indicator pembelajaran. Permainan sains bagi anak usia dini merupakan kegiatan bermain yang mengasah kognitif anak dalam aspek perkembangannya berlandaskan sains.

\section{Media Pembelajaran}

Menurut 26 media merupakan kata jamak dari medium yang artinya pengantar atau perantara yang digunakan oleh komunikator untuk menyampaikan pesan kepada komunikasi dalam mencapai efek tertentu.

Media pembelajaran adalah pengantar pesan dalam suatu materi yang akan disampaikan kepada penerima pesan (anak/siswa). Menurut 27 fungsi media

\footnotetext{
${ }^{24}$ Tursinawati, “Penguasaan Konsep Hakikat Sains Dalam Pelaksanaan Percobaan Pada Pembelajaran Ipa Di Sdn Kota Banda Aceh," Jurnal Pesona Dasar 2, no. 4 (2016): 72-84, https://doi.org/10.24815/pear.v7i2.14753.

25 (Tursinawati, 2016).

26 (Kustiawan, 2016, p. 5)

27 (Kustiawan, 2016, p. 9)
} 
pembelajaran dibagi menjadi dua bagian, yaitu kapasitas primer dan kapasitas tidak umum, secara garis beser sebagai berikut:

1. Fungsi utama media pembelajaran yaitu sebagai sarana bantu untuk mewujudkan situasi pembelajaran yang lebih efektif.

2. Fungsi khusus: a) menonjol bagi siswa; b) menjelaskan penyampaian pesan; c) mengatasi keterbatasan ruang, waktu, dan biaya; d) menjauhi verbalisme dan distorsi; e) untuk memberlakukan dan memperlancar latihan belajar anak-anak.

Media pembelajarn merupakan sarana untuk menyalurkan pesan pembelajaran dan informasi. Media pembelajaran yang dirancang dengan baik akan sangat membantu pelajar mencapai tujuan pembelajaran. Masing-masing jenis media pembelajaran memiliki karakteristik, keuntungan, dan kerugian. Oleh karena itu, perlu untuk membantu perencanaan sistematis untuk menggunakan media instruksional. Unsur media pembelajaran terdiri dari alat perangkat kerasnya serta isi pesan (konten) yang akan disampaikan/ disalurkan oleh media tersebut.

Menurut Kemp dan Dayton 198528 manfaat media dalam pembelajaran yaitu:

1. Penyampaian materi pelajaran dapat diseragamkan.

2. Proses pembelajaran menjadi lebih jelas dan menarik.

3. Proses pembelajaran menjadi lebih interaktif.

4. Efisiensi dalam waktu dan tenaga.

5. Meningkatkan kualitas hasil belajar siswa.

6. Media memungkinkan proses belajar dapat dilakukan dimana saja dan kapan saja.

7. Media dapat menumbuhkan sikap positif siswa terhadap materi dan proses belajar.

8. Merubah peran guru kearah yang lebih positif dan produktif.

\section{METODE PENELITIAN}

\section{Desain Penelitian}

Metode penelitian yang digunakan dalam penelitian ini adalah jenis pengembangan Educational Design Researct (EDR). Menurut Mckenney dan Reeves 201329 EDR adalah jenis penelitian yang pada pelaksanaannya terdapat proses berulang (iterative) untuk mengembangan solusi dari masalah pendidikan yang kompleks. Solusi tersebut dapat berupa produk (media, sumber belajar, dll), proses (strategi, metode, model pembelajaran), atau program (loka karya, pelatihan, dll).

Menurut Plomp, 201330 tujuan dari penelitian ilmiah adalah untuk memberikan sedikit pengetahuan dan menambah praktik pengembangan lebih

\footnotetext{
28 (dalam Firmadani, 2020)

29 (dalam Qonita, 2018)

30 (dalam Qonita, 2018)
} 
lanjut, dan untuk menerangi kemajuan dinamis dan strategi dalam pelatihan. Hal tersebut dapat diwujudkan melalui satu atau lebih desain penelitian.

Secara umum desain penelitian bertujuan untuk merancang suatu penelitian. Desain penelitian menurut 31 merupakan rancangan penelitian yang digunakan sebagai pedoman dalam melakukan proses penelitian. Desain penelitian bertujuan untuk memberi pegangan yang jelas dan terstruktur kepada penelitian dalam melakukan penelitiannya. Menurut Fachruddin 200932

Di dalam penelitian Educational Design Researct (EDR) terdapat proses siklus (iterative) meliputi analisis, perancangan, pengembangan evaluasi, dan revisi menurut Akker, et al $2006^{33}$. Model EDR penelitian ini menggunakan model dari 34

Gambar 3.1

Bagan Alur Penelitian Model Reeves

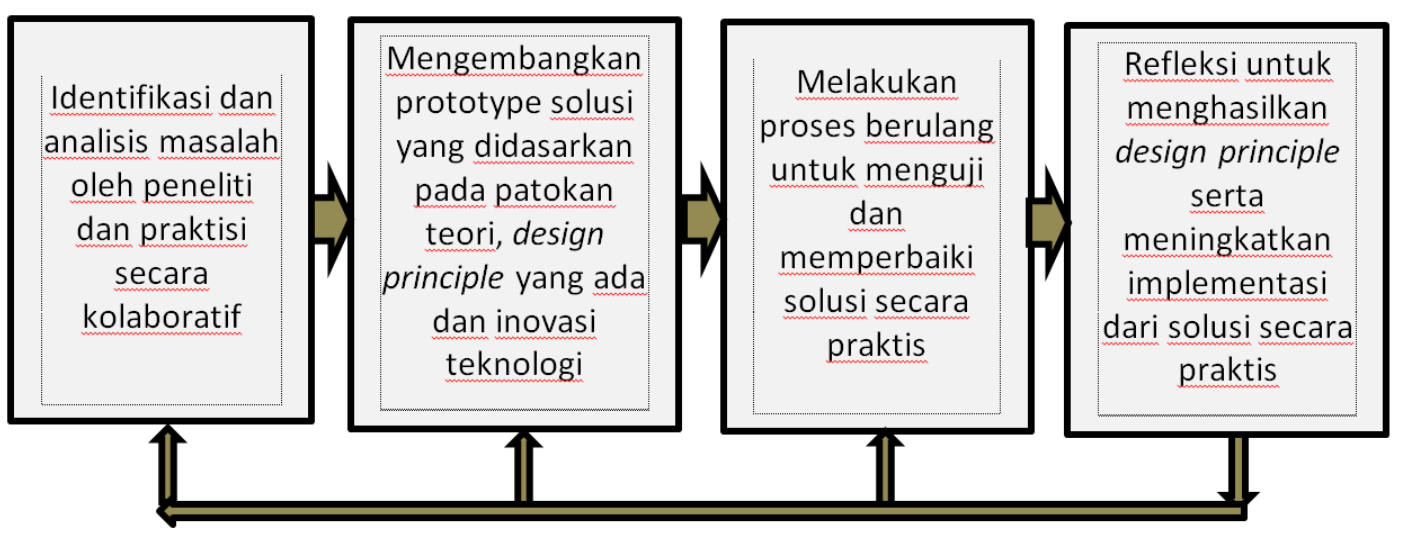

Identifikasi dan analisis masalah oleh peneliti dan praktisi secara kolaboratif

1. Identifikasi masalah: masalah tersebut adalah belum terfasilitasi terbentuknya kreativitas anak secara metode pembelajaran yang terarah dan optimal. Dengan itu peneliti melakukan pemecahan masalah (problem solving) untuk anak dalam permainan sains. Berlatar belakang masalah tersebut, maka mucul ide untuk memfasilitasi kreativitas anak usia dini dalam media barang bekas yang telah ditentukan dalam suatu permainan sains sesuai tema pembelajaran. Yang berjudul "Pengembangan Permainan Sains Problem Solving Cardboard Box Lego untuk Memfasilitasi Kreativitas Anak Usia Dini".

2. Analisis masalah: masalah yang dihadapi anak adalah kurangnya anak mengembangkan kreativitas dengan permainan oleh karena itu peneliti mebuat sebuah permainan sain dengan pembelajaran problem solving untuk

31 Bella Karlina, "Pengaruh Manajaemen Fasilitas Terhadap Mutu Layanan Diklat Di Pusat Pengembangan Dan Pemberdayaan Pendidik Dan Tenaga Kependidikan Bidang Mesin Dan Teknik Industri," NASPA Journal 42, no. 4 (2015): 1.

32 (dalam Karlina, 2015)

33 (dalam Qonita, 2018)

34 (Reeves 2006, Plomp, 2007, dalam Lidinillah, 2012) 
memfasilitasi perkembanganya dalam kreativitas dengan model cardboard box lego.

3. Kolaboratif antara peneliti dan praktisi: kolaboratif sama dengan kolaborasi yaitu merupakan kerjasama, interaksi, kompromi, lembaga atau yang terlibat dalam penelitian serta pihak-pihak yang terlibat secara langsung maupun tidak langsung yang menerima akibat dan manfaat.

Mengembangkan prototype solusi yang didasarkan pada patokan teori, design principle yang ada dan inovasi teknologi

1. Prototype adalah sistem atau rancangan produk dasar. Dalam tahap ini dasar perancangan pengembangan prototype solusi akan berdasarkan pada patokan teori, design principle yang ada dan inovsi teknologi.

2. Patokan teori: mengkaji berbagai teori dan konsep yang dijadikan acuan dalam "Pengembangan Permainan Sains Problem Solving Cardboard Box Lego untuk Memfasilitasi Kreativitas Anak Usia Dini".

3. Design principle: menyusun draft rancangan dalam "Pengembangan Permainan Sains Problem Solving Cardboard Box Lego untuk Memfasilitasi Kreativitas Anak Usia Dini" berdasarkan empirik dan teori.

4. Inovasi teknologi: memberikan inovasi teknologi dalam proses mengembangkan prototype solusi. Inovasi teknologi merupakan ide gagasan yang dilandasi sebagai hal yang baru maupun pun yang berdasarkan pengadopsian dalam ruang lingkup science.

5. Cara mengembangkan prototype solusi: berdasaran hasil pencarian bahan teori serta diproses menjadi design principle yang ada dan inovasi teknologi. Setelah itu melakukan diskusi dan revisi draf bersama dosen pembimbing, serta dilanjutkan diskusi dan revisi dengan para praktisi.

\section{Melakukan proses berulang untuk menguji dan memperbaiki solusi secara praktis}

1. Dalam tahap ini diharuskan melakuakn proses berulang untuk menguji dan memperbaiki solusi secara praktisi. Penelitian ini yang berjudul "Pengembangan Permainan Sains Problem Solving Cardboard Box Lego untuk Memfasilitasi Kreativitas Anak Usia Dini"

2. Menguji: dengan menguji indicator keberhasilan apakah sesuai dengan yang diharapkan dalam penelitian.

3. Memperbaiki solusi secara praktisi: setelah menguji maka akan diperbaiki/dievaluasi dan diberi solusi yang baik.

4. Revisi: setelah tahapan perbaiki solusi dari hasil proses evaluasi dan solusi maka, diteruskan dengan penyempurnaan dengan cara revisi guna untuk mengkoreksi dan mempertahankan kualitas sebuah informasi serta data yang disampaikan.

5. Cara melakukan proses berulang: penelitian dengan cara menguji, memperbiki, serta merevisi secara berulang agar mendapatkan hasil yang lebih baik. 


\section{Refleksi untuk menghasilkan design principle serta meningkatkan implementasi dari solusi secara praktis}

Dalam tahapan ini refleksi untuk menghasilkan design principle serta meningkatkan implementasi dari solusi secara praktisi. Penelitian ini yang berjudul “Pengembangan Permainan Sains Problem Solving Cardboard Box Lego untuk Memfasilitasi Kreativitas Anak Usia Dini"

1. Cara menghasilkan design principle: mengolah dan menganalisa data temuan secara keseluruhan terbaik renspons guru dan implikasi terhadap pengembangan kreativitas proses permainan sains.

2. Cara meningkatkan implementasi dari solusi secara praktisi: setelah di analisis dilakukan penyempurnaan untuk implementasi kemudian dilakukan validasi akhir oleh ahli/praktisi.

3. Gambaran dan cara menghasilkan proses refleksi: setelah mengasilkan design principle dan meningkatkan impementasi dari solusi praktis maka refleksi dalam penelitian ini merupakan pembelajaran harus sistematis dan analitis. Agar mampu menentukan mengapa pembelajaran tidak memuaskan segingga dapat diperbaiki diwaktu mendatang.

\section{PEMBAHASAN}

\section{Identifikasi dan Analisis}

Berdasarkan studi literatur mengenai media permainan di PAUD masih belum menggunakan media permainan sains problem solving dikarenakan guru belum memahami betul mengenai media permainan ini. Namun untuk pembelajaran sains sudah dilakukan di PAUD tetapi jarang dilakukan pembelajaran ini. Banyak sekali konsep sains yang dapat diajarkan pada anak usia dini, tetapi tidak dibantu oleh media permainan yang memadai. Media permainan ini merupakan media permainan yang dapat membatu dalam pembembelajaran yang mempuni dalam mengembangkan aspek perkembangan bagi anak. Hasil studi literatur oleh peneliti terhadap penggunaan media permainan yang dilakukan oleh peneliti untuk digunakan di PAUD masih

\section{Mengembangkan Prototype}

Pengembangan media permainan ini dibuat dengan merujuk pada kurikulum 2013 yang mengembangkan aspek kognitif untuk memfasilitasi kreativitas anak. Penelitian akan mengembangkan media permainan untuk anak yang sesuai dengan kurikulum 2013. Pengembangan media permainan ini di tujukan untuk anak kelompok B usia 5-6 tahun dengan Tema Alat Transportasi, Sub Tema Alat Trasportasi Darat dan Sub-sub Tema Model Alat Transportasi Darat (beroda). Jenis media permainan ini yang dikembangkan secara individual atau personal yang diiberikan kepada masing-masing anak. Bentuk media permainan sains ini sendiri 
adalah Cardboard Box Lego yang membantu anak untuk menemukan yaitu konsep model alat tarsportasi darat (mobil, motor, truk, bis, bajai, kereta api). Aspek perkembangan kognitif ini dalam menumbuhkan kreativitas anak yang difasilitasi oleh media permainan sains bagi anak ini secara spesifik yaitu mengamati, mengklasifikasi dan mengkomunikasikan. Berikut merupakan rancangan media permainan sains problem soling Cardboard Box Lego yang dikembangkan oleh peneliti:

Tabel 4.1

Rancangan Media Permainan Sains Problem Solving Cardboard Box Lego untuk Memfasilitasi Kreativitas Anak Usia Dini

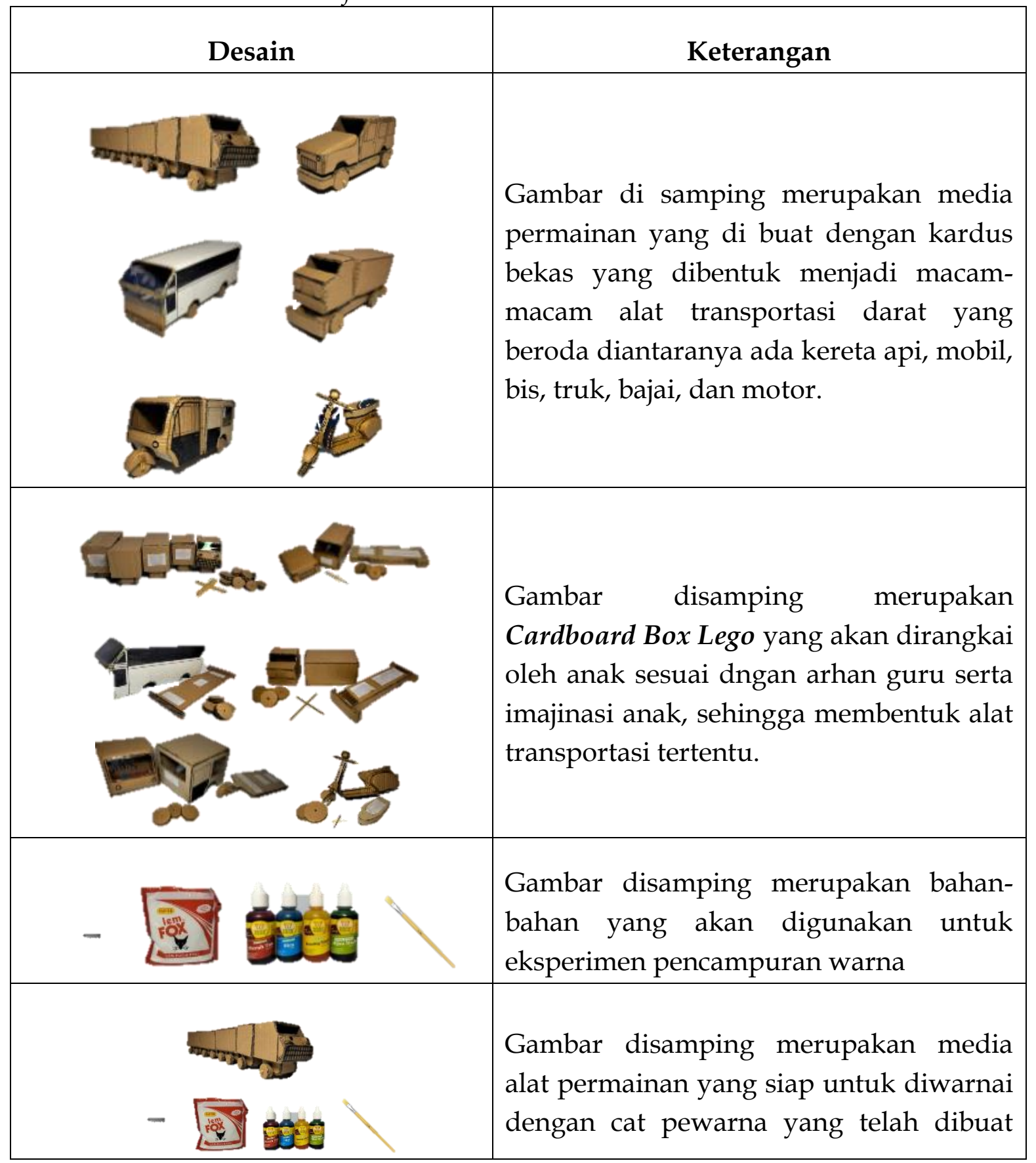




\begin{tabular}{|l|l|}
\hline & oleh anak \\
\hline & $\begin{array}{l}\text { Gambar disamping merupakan alat yang } \\
\text { digunakan untuk membersihkan tangan } \\
\text { setelah kegiatan bermain }\end{array}$ \\
\hline
\end{tabular}

Pengembangan media ini disesuaikan dengan kurikulum 2013 memporioritaskan dalam aspek perkembangan kognitif anak dalam kreativitasnya sehingga dapat lebih berpacu untuk perkembangan tersebut.

\section{Menguji dan Memperbaiki Solusi secara Praktis}

Pada tahap ini yaitu proses berulang untuk menguji dan memperbaiki solusi secara praktis. Dalam tahap ini peneliti melakukan perbaikan-perbaikan guna menghasilkan instrumen penelitian kinerja yang layak digunakan.

1. Validasi ahli

Pada tahap ini dilakukan validasi oleh validator ahli pada rancangan produk awal berupa rubik penilaian kinerja. Validasi dilakukan guna mengetahui kuatitas produk kevalidan rubik penilaian berdasarkan judgment ahli. Peneliti melakukan validasi ahi kepada 3 validator ahli. Hal ini dilakukan guna mengetahui kualitas kelayakan produk sebelum di uji coba.

2. Uji coba tahapan pertama

Pada tahapan uji coba pertama dilakukannya untuk pengembangan permainan sains problem solving cardboard box lego untuk memfasilitasi kreativitas anak usia dini. Waktu yang disediakan 60 menit dengan anak 8 orang, kreativitas anak keliatan sangat antusias, hanya desains media permainan kurang praktis serta waktu yang tersedia sangat terbatas sehingga dalam pewarnaan model alat transportasi belum dapat terselesaikan sesuai harapan.

3. Uji coba tahapan kedua

Pada tahapan uji coba kedua akan dilakukannya yaitu; a) desains permainan akan dibuat lebih praktis; b) penambahan waktu, maka dari itu dalam tahap kedua waktu akan ditambah menjadi 120 menit untuk mencapai keberhasilan yang diharapkan.

Refleksi untuk menghasilkan design principle serta meningkatkan implementasi dari solusi secara praktis

Dalam proses pengembangan permainan sains problem solving cardboard box lego dan uji coba penelitian yang sudah dilakukan, telah diimplementasikan bahwa lego sangat cocok untuk anak usia dini dalam memfasilitasi kreativitasnya serta mempermudah dalam proses pembelajaran yang akan dilakukannya.

Media ini dapat menjadikan sarana stimulus yang harus di perbaikan dalam bagian-bagian fungsi yaitu: 1) Desains lego dibuat lebih praktis jangan menyulitkan 
anak dalam merangkai model alat transportasi darat (mobil, motor, truk, bis, bajai, kereta api); 2) Dalam waktu harus memadai sehingga keberhasilan tercapai sesuai harapan.

\section{KESIMPULAN}

Berdasarkan penelitian dan pengembangan Media Permainan Cardboard Box Lego untuk memfasilitasi kreativitas Anak Usia Dini dengan Tema Alat Transportasi, Sub Tema Transportasi Darat dan Sub-sub Tema Model Alat Transportasi Darat (Mobil, Motor, Bajai, Bis, Truk, Kereta Api), dapat disimpulkan: layak dan baik untuk dijadikan media pembelajaran pada anak usia dini dalam merangsang, memfasilitasi, mengembangkan, dan meningkatkan daya imajinasi dan kreativitas anak usia dini, sehingga kognitifnya dapat berkembang dalam menemukan aspek perkembangan kognitif anak untuk memfasilitasi kreativitas anak usia dini.

\section{REFRENSI}

Bujuri, Dian Andesta. "Analisis Perkembangan Kognitif Anak Usia Dasar Dan Implikasinya Dalam Kegiatan Belajar Mengajar." LITERASI (Jurnal Ilmu Pendidikan) 9, no. 1 (2018): 37. https://doi.org/10.21927/literasi.2018.9(1).37-50.

Dindin Abdul Muiz Lidinillah, S.Si., S.E., M.Pd. "Design Research Sebagai Model Penelitian Pendidikan." Universitas Pendidikan Indonesia Kampus Tasikmalaya, 2012.

Fadilatunnisa, Adella, Nur Khasanah, and Supriyati H Rahayu. "Bermain Lego Sebagai Pembelajaran Harian Untuk Mengembangkan Kreatifitas Anak Usia Dini” 3 (2021). https://doi.org/10.35473/ijec.v3i2.1005.

Fakhriyani, Diana Vidya. "Pengembangan Kreativitas Anak Usia Dini." Wacana Didaktika 4, no. 2 (2016): 193-200. https://doi.org/10.31102/wacanadidaktika.4.2.193-200.

Firmadani, Fifit. "Media Pembelajaran Berbasis Teknologi Sebagai Inovasi Pembelajaran Era Revolusi Industri 4.0.” Prosiding Konferensi Pendidikan Nasional, no. ISSN: 2654-8607 (2020): 93-97.

Handayani, F. "Peningkatan Kreativitas Seni Rupa Anak Melalui Media Tekstur Di TK Permata Intan," 2019. https://repository.ar-raniry.ac.id/id/eprint/15219/.

Irfan Taufan Asfar \& Syarif Nur. Model Pembelajaran PPS (Problem Posing \& Solving). Sukabumi: CV Jejak, 2018.

Karlina, Bella. "Pengaruh Manajaemen Fasilitas Terhadap Mutu Layanan Diklat Di Pusat Pengembangan Dan Pemberdayaan Pendidik Dan Tenaga Kependidikan Bidang Mesin Dan Teknik Industri." NASPA Journal 42, no. 4 (2015): 1.

Nadila, Putri. "Pentingnya Melatih Problem Solving Pada Anak Usia Dini Melalui Bermain." Pedagogi: Jurnal Ilmu Pendidikan 21, no. 1 (2021): 51-55. https://doi.org/10.24036/pedagogi.v21i1.965. 
Paramita, Novia, Peduk Rintayati, and Siti Wahyuningsih. "Peningkatan Kemampuan Kognitif Anak Usia 5-6 Tahun Melalui Penerapan Permainan Sains." Kumara Cendekia 7, no. 2 (2019): 126. https://doi.org/10.20961/kc.v7i2.36372.

Qonita. "Pengembangan Science Didactical Book Untuk Menumbuhkan Keterampilan Proses Sains." Universitas Pendidikan Indonesia 6(11) (2018): 5-24.

Rachmandani, Anistya. "Peningkatan Kreativitas Anak Melalui Media Bahan Bekas Pada Siswa RA Kelompok B Di RA Miftahul Huda 1 Lopait Kecamatan Tuntang Kabupaten Semarang Tahun Pelajaran 2016/2017.” Skripsi, 2017, 1.

Stricker, Laura W., and David M. Sobel. "Children's Developing Reflections on and Understanding of Creativity." Cognitive Development 55 (2020). https://doi.org/10.1016/j.cogdev.2020.100916.

Tursinawati. "Penguasaan Konsep Hakikat Sains Dalam Pelaksanaan Percobaan Pada Pembelajaran Ipa Di Sdn Kota Banda Aceh.” Jurnal Pesona Dasar 2, no. 4 (2016): 72-84. https://doi.org/10.24815/pear.v7i2.14753.

Usep Kustiawan. Pengembangan Media Pembelajaran Anak Usia Dini. Malang: Penerbit Gunung Samudra, 2016.

Wartini, Ii, Hilman Mangkuwibawa, Cecep Anwar, Kota Bandung, Jurusan Pendidikan, Islam Anak, Usia Dini, Jurusan Pendidikan, and Agama Islam. "Penerapan Metode Problem Solving." Tunas Siliwangi 3, no. 2 (2017): 175-80.

Yeni Rachmawati \& Euis Kurniati. Strategi Pengembangan Kreativitas Pada Anak Usia Taman Kanak-Kanak. Jakarta: Prenadamedia Group, 2019. 